\title{
Evaluation of Anti-Inflammatory and Analgesic Activities of Methanolic Extract of Aitchisonia Rosea in Albino Mice
}

\author{
Shahid Rasool', Ambreen Malik Uttra ${ }^{1, *}$, Mehreen Malik Uttra ${ }^{2}$, Faheem Ahmed ${ }^{3}$, Khizar Abbas ${ }^{4}$ \\ ${ }^{1}$ College of Pharmacy, University of Sargodha, Sargodha-44100, Pakistan \\ ${ }^{2}$ DHQ Teaching Hospital Sargodha, Sargodha-44100, Pakistan \\ ${ }^{3}$ Faculty of Pharmacy, University of Central Punjab, Lahore-54000, Pakistan \\ ${ }^{4}$ Faculty of Pharmacy, Bahaudin Zakaria University, Multan-66000, Pakistan
}

Authors' Contributions

1,2 Conception \& Study Design, Data Analysis, Drafting, Critical review

3,4,5 Conception \& Study Design, Data collection and processing, Data Analysis,

Critical review

\section{Article info.}

Received: February 15, 2020

Accepted: July 23, 2020

Funding Source: Nil

Conflict of Interest: Nil

Cite this article: Rasool S, Uttra AM, Uttra MM, Ahmed F, Abbas K. Evaluation of AntiInflammatory and Analgesic Activities of Methanolic Extract of Aitchisonia Rosea in Albino Mice. RADS J Pharm Pharm Sci. 2020; 8(1):31-36.

*Address of Correspondence Author: ambreenuttra@gmail.com

\section{ABSTRACT}

Objective: Current analysis aims at in-vivo investigation of analgesic and anti-inflammatory activities of Aitchisonia rosea methanolic extract.

Methods: Albino mice (20-30 g) were used in the study. Extract at 200, 400 and $800 \mathrm{mg} / \mathrm{kg}$ doses was tested against egg albumin and carrageenan induced mice paw edema along with formalin persuaded paw licking and acetic acid prompted writhing for analgesic activity.

Results: Results depicted dose reliant and significant $(p<0.001)$ inhibition of carrageenan as well as egg albumin brought paw edema, abdominal constrictions/ hind limb stretching tempted by acetic acid and formalin instigated paw licking. Capability of crude extract to halt inflammatory and analgesic response was akin to that of ibuprofen in all models.

Conclusion: The current findings support the use of Aitchisonia rosea for inflammatory conditions, which might be attributed to its previously proven high alkaloid, flavonoids, phenol, tannins content and free radical scavenging activity.

Key Words: Aitchisonia rosea, analgesic, ibuprofen, anti-inflammatory.

\section{INTRODUCTION}

Inflammation, a protective reaction yields an array of inflammatory intermediaries to infection, irritation and tissue injury to exterminate the irritant and uphold tissue repair [1]. Moreover, free radicals also contribute towards the pathogenesis of inflammation. During inflammation, reactive oxygen species (ROS) increase unusually owing to the action of free radicals on molecular oxygen, which causes an imbalance among oxidizing agents and anti-oxidant system of body. The oxidative stress ensues in inflammatory processes that impair the cellular constituents [2]. Hence, pharmacological agents are required to relieve the damage caused by inflammatory response and associated algesia, for instance, NSAIDs (nonsteroidal anti-inflammatory drugs), opiates and corticosteroids. Nevertheless, because of frequent use of these drugs, unpleasant effects (Gl bleeding, peptic ulcer etc) occur repeatedly, particularly when higher doses are used for prolonged duration. Hence, natural products obtained from medicinal plants are becoming ideal alternative therapies [3]. In this aspect, secondary metabolites of numerous medicinal plants have been shown to be active in the management of pain and inflammation [2].

Aitchisonia rosea Hemsl. ex Aitch (Family: Rubiaceae) plant is a native to Pakistan 
(Baluchistan), Afghanistan and Iran [4]. Traditionally it is used for the treatment of dermal infections in Baluchistan. The aerial parts of Aitchisonia rosea have been reported to possess anti-convulsant, antimicrobial and hemolytic effect [4]. Indeed, it has been confirmed that Aitchisonia rosea extract exhibit robust anti-oxidant potential against reducing power assay and DPPH free radical scavenging assay [5], mainly attributed to its polyphenolic phytoconstituents, identified through HPLC technique [4]. A large number of flavonoids and other phenolics have been proved their noteworthy effects on inflammatory processes [6]. Phenolic compounds exert antiinflammatory property by impeding pro-inflammatory mediators production, inhibiting triggered immune cells, altering eicosanoid synthesis, preventing cyclooxygenase-2/nitric oxide synthase and acting as free radical scavengers [7]. Since, ROS and free radicals are prime mediators that sustain or incite inflammatory procedures, their deactivation by antioxidants and radical scavengers can mitigate inflammation so, based upon the reported anti-oxidant nature of Aitchisonia rosea and imperative role of polyphenolic constituents in prevention of inflammatory processes, the existing investigation was conducted to appraise its potential against inflammation.

\section{MATERIALS AND METHODS}

\section{Chemicals}

In the current study, carrageenan (Sigma, USA), fresh hen egg-albumin, formalin (Merck, Germany), acetic acid (Sigma, USA) and ibuprofen were used.

\section{Collection and Extraction of Plant}

The aerial parts (stems and branches) of Aitchisonia rosea were acquired from Quetta, Pakistan. The plant was recognized and verified by taxonomists, Prof. Zaheer Ahmad Khan, GC University Lahore, and Prof. Rasool Bakhsh Tareen, University of Balochistan, Quetta. For further citation, voucher sample (No. 1911) was kept at Sultan Ayub Herbarium, GC University Lahore. The plant were shade dried at room temperature. The powdered plant $(5 \mathrm{~kg}$ ) was dipped in $6 \mathrm{~L}$ methanol $(100 \%)$ for three days with frequent stirring every day. This procedure was repeated thrice. It was then filtered using Whattman filter paper. The Aitchisonia rosea methanol extract (ARME) was concentrated and kept at $4{ }^{\circ} \mathrm{C}$ in a refrigerator [4].

\section{Experimental Animals}

Albino mice $(20-30 \mathrm{~g})$ were employed in each test. Mice were kept in propylene cages under controlled environment of $24 \pm 1{ }^{\circ} \mathrm{C}$ and $12 \mathrm{~h}$ light/dark cycles and ventilation. Appropriate feed and water were provided ad libitum unless otherwise specified. All mice were treated as per standard protocols directed by National Research Council, 1996 [8]. The animal studies were permitted by Animal Ethics Committee, University of Sargodha.

\section{Carrageenan Induced Paw Edema of Inflammation}

Mice were divided into 5 groups $(n=5)$. Group I served as control and given distilled water (2 ml $/ \mathrm{kg}$ p.o). Group II, III, IV were administered 200, 400, 800 $\mathrm{mg} / \mathrm{kg}$ ARME orally, respectively whereas, group $\mathrm{V}$ was given $40 \mathrm{mg} / \mathrm{kg}$ ibuprofen p.o. The edema was induced into sub-planar surface of right hind paw by inserting $0.1 \mathrm{ml}$ carrageenan ( $1 \% \mathrm{w} / \mathrm{v}$ in saline), 1 hour after treatment. Diameter of injected paw was assessed at $0,1^{\text {st }}, 2^{\text {nd }}$ and $3^{\text {rd }} \mathrm{h}$ of treatment using digital vernier calliper [9].

\section{Egg Albumin Induced Paw Edema of Inflammation}

Mice were segregated into 5 groups $(n=5)$. Group I (control) was given orally $2 \mathrm{ml} / \mathrm{kg}$ distilled water. Group II, III, IV were administered ARME orally at 200, 400 and $800 \mathrm{mg} / \mathrm{kg}$ doses, in that order. Group V was given ibuprofen $(40 \mathrm{mg} / \mathrm{kg})$ orally. The fresh hen's egg albumin $(0.1 \mathrm{ml})$ was administered into right hind paw of all mice after $1 \mathrm{~h}$ of treatment. Then, injected paw diameter was monitored at $0,1^{\text {st }}, 2^{\text {nd }}$ and $3^{\text {rd }} \mathrm{h}$ of administration of test material via digital vernier calliper [9].

\section{Acetic acid Induced Writhing Model of Analgesia}

The mice were segregated into 5 groups $(n=5)$. Group 1 i.e. control was administered $2 \mathrm{ml} / \mathrm{kg}$ distilled water orally. The groups II, III, IV received ARME at 200, $400,800 \mathrm{mg} / \mathrm{kg}$ doses orally, correspondingly. Group $\mathrm{V}$ was given ibuprofen $(40 \mathrm{mg} / \mathrm{kg}$, p.o.). The solution of acetic acid $(10 \mathrm{ml} / \mathrm{kg}, 0.6 \%$ in normal saline) was administered i.p. to each mice, $30 \mathrm{~min}$ after administering the test substance. Number of writhings described by abdominal contractions and stretching with hind limb jerk was calculated for 5-15 min subsequent to acetic acid inoculation. The reaction of mice in treatment groups was equated with control group mice [10]. 


\section{Formalin Induced Paw Licking Model of Analgesia}

The 5 groups of mice $(n=5)$ were kept on overnight fasting. Group I i.e., control group was given $2 \mathrm{mg} / \mathrm{kg}$ distilled water orally. Whereas, groups II, III, IV mice were administered orally 200,400 and $800 \mathrm{mg} / \mathrm{kg}$ doses of ARME, correspondingly. Whereas, group V was given ibuprofen (40 mg/kg, p.o.). $20 \mu \mathrm{l}$ of formalin solution (2.5\%) was inoculated into sub-plantar region of left hind paw of all mice after $1 \mathrm{~h}$ of treatment. The time taken to lick formalin injected paw was observed for $30 \mathrm{~min}$ immediately after injecting formalin [10].

\section{Statistical Analysis}

The data was accessed as mean \pm SEM and statistically evaluated with one-way and two-way ANOVA accompanied by Bonferroni posttest via Graph Pad Prism 5. The statistical significance was taken at $p<0.05$.

\section{RESULTS}

\section{Effect of ARME on Carrageenan Induced Paw Edema}

In mice administered 200, 400 and $800 \mathrm{mg} / \mathrm{kg}$ doses of ARME, constant dose reliant and considerable $(\mathrm{p}<0.001)$ decline in paw diameter $(3.17 \mathrm{~mm} \pm 0.25$, $3.00 \mathrm{~mm} \pm 0.14$ and $2.90 \mathrm{~mm} \pm 0.19$, respectively) was noted at $3^{\text {rd }} \mathrm{h}$ of treatment, compared to control group mice $(4.60 \pm 0.09 \mathrm{~mm})$. Furthermore, ibuprofen $(40 \mathrm{mg} / \mathrm{kg})$ significantly $(p<0.001)$ decreased paw diameter (3.32 $\mathrm{mm} \pm 0.14$ ), when compared to control mice, but reduction in edema formation was observed to be less in contrast to ARME groups (Table 1).

\section{Effect of ARME on Egg Albumin Induced Paw Edema}

The methanolic extract of plant at all dose levels showed a considerable $(p<0.001)$ decline in paw edema at $3^{\text {rd }} \mathrm{h}$, particularly with $800 \mathrm{mg} / \mathrm{kg}$ dose, compared to control group. Nonetheless, reduction in paw diameter of mice with ibuprofen treatment was significantly $(p<0.001)$ lesser than extract treated mice at $3^{\text {rd }} \mathrm{h}$ of treatment. The paw diameter of mice treated with 200, 400, $800 \mathrm{mg} / \mathrm{kg}$ ARME and 40 $\mathrm{mg} / \mathrm{kg}$ of ibuprofen were found to be $2.88 \mathrm{~mm} \pm 0.12$, $2.80 \mathrm{~mm} \pm 0.06,2.66 \mathrm{~mm} \pm 0.31$ and $3.19 \mathrm{~mm} \pm 0.31$ respectively as compared to control $(3.92 \pm 0.14)$ at $3^{\text {rd }}$ h (Table 2).

Table 1. Effect of ARME on carrageenan induced paw edema.

\begin{tabular}{|c|c|c|c|c|}
\hline \multirow{2}{*}{$\begin{array}{l}\text { Animal } \\
\text { Groups }\end{array}$} & \multicolumn{4}{|c|}{ Change in paw diameter ( $\mathrm{mm})$} \\
\hline & $\mathbf{O h}$ & $1^{\text {st }} h$ & $2^{\text {nd }} h$ & $3^{\text {rd } h}$ \\
\hline $\begin{array}{l}\text { Control } \\
(2 \mathrm{ml} / \mathrm{kg})\end{array}$ & $3.62 \pm 0.1$ & $4.11 \pm 0.08$ & $4.39 \pm 0.12$ & $4.60 \pm 0.09$ \\
\hline $\begin{array}{c}\text { ARME } \\
(200 \mathrm{mg} / \mathrm{kg})\end{array}$ & $3.97 \pm 0.10$ & $3.77 \pm 0.53^{* * *}$ & $3.41 \pm 0.17^{* * *}$ & $3.17 \pm 0.25^{\star * *}$ \\
\hline $\begin{array}{c}\text { ARME } \\
(400 \mathrm{mg} / \mathrm{kg})\end{array}$ & $3.84 \pm 0.13$ & $3.59 \pm 0.15^{\star * *}$ & $3.28 \pm 0.16^{* * *}$ & $3.00 \pm 0.14^{* * *}$ \\
\hline $\begin{array}{c}\text { ARME } \\
(800 \mathrm{mg} / \mathrm{kg})\end{array}$ & $3.64 \pm 0.13$ & $3.47 \pm 0.17^{\star * \star}$ & $3.22 \pm 0.16^{\star \star *}$ & $2.90 \pm 0.19^{* \star *}$ \\
\hline $\begin{array}{l}\text { Ibuprofen } \\
\text { (40 mg/kg) }\end{array}$ & $3.90 \pm 0.03$ & $3.69 \pm 0.13^{* \star *}$ & $3.54 \pm 0.22^{* * *}$ & $3.32 \pm 0.14^{* * *}$ \\
\hline
\end{tabular}

Values are stated as mean $\pm \operatorname{SEM}(n=5) .{ }^{* * *}=p<0.001$, compared to control. ARME $=$ Aitchisonia rosea methanol extract 
Table 2. Effect of ARME on egg albumin induced paw edema.

\begin{tabular}{|c|c|c|c|c|}
\hline \multirow{2}{*}{$\begin{array}{l}\text { Animal } \\
\text { Groups }\end{array}$} & \multicolumn{4}{|c|}{ Change in paw diameter $(\mathrm{mm})$} \\
\hline & $\mathbf{O h}$ & $1^{\text {st }} h$ & $2^{\text {nd }} h$ & $3^{\text {rd }} h$ \\
\hline $\begin{array}{l}\text { Control } \\
(2 \mathrm{ml} / \mathrm{kg})\end{array}$ & $3.56 \pm 0.14$ & $3.72 \pm 0.15$ & $4.71 \pm 0.16$ & $4.92 \pm 0.18$ \\
\hline $\begin{array}{c}\text { ARME } \\
(200 \mathrm{mg} / \mathrm{kg})\end{array}$ & $3.82 \pm 0.13$ & $3.55 \pm 0.1^{* * *}$ & $3.10 \pm 0.06^{* * *}$ & $2.88 \pm 0.12^{\star \star \star}$ \\
\hline $\begin{array}{c}\text { ARME } \\
(400 \mathrm{mg} / \mathrm{kg})\end{array}$ & $3.66 \pm 0.15$ & $3.36 \pm 0.13^{* * *}$ & $3.09 \pm 0.14^{* * *}$ & $2.80 \pm 0.06^{\star \star *}$ \\
\hline $\begin{array}{c}\text { ARME } \\
(800 \mathrm{mg} / \mathrm{kg})\end{array}$ & $3.52 \pm 0.13$ & $3.29 \pm 0.22^{* \star *}$ & $3.02 \pm 0.34^{\star \star *}$ & $2.66 \pm 0.31^{* * *}$ \\
\hline $\begin{array}{l}\text { Ibuprofen } \\
\text { (40 mg/kg) }\end{array}$ & $3.70 \pm 0.12$ & $3.50 \pm 0.34^{\star *}$ & $3.38 \pm 0.11^{* \star *}$ & $3.19 \pm 0.31^{\star \star \star}$ \\
\hline
\end{tabular}

Values are stated as mean $\pm \operatorname{SEM}(n=5) .{ }^{* *}=p<0.01,{ }^{* * *}=p<0.001$, compared to control. Aitchisonia rosea methanol extract

Table 3. Effect of ARME on acetic acid induced writhing.

\begin{tabular}{|c|c|c|}
\hline \multirow{2}{*}{$\begin{array}{l}\text { Animal } \\
\text { Groups }\end{array}$} & No. of Writhing & \multirow{2}{*}{$\begin{array}{c}\text { Inhibition } \\
(\%)\end{array}$} \\
\hline & Mean \pm SEM & \\
\hline Control (2 ml/kg) & $48.6 \pm 1.41$ & 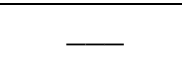 \\
\hline ARME (200 mg/kg) & $25.4 \pm 0.92^{\star \star \star}$ & 47.73 \\
\hline ARME (400 mg/kg) & $20.2 \pm 0.68^{* * *}$ & 58.43 \\
\hline ARME $(800 \mathrm{mg} / \mathrm{kg})$ & $15.4 \pm 0.20^{\star \star *}$ & 68.31 \\
\hline Ibuprofen (40 mg/kg) & $18.2 \pm 0.90^{* * *}$ & 62.55 \\
\hline
\end{tabular}

Values are stated as mean \pm SEM $(n=5) .{ }^{* * *}=p<0.001$ compared to control. Aitchisonia rosea methanol extract

Table 4. Effect of ARME on formalin induced paw licking.

\begin{tabular}{|c|c|c|}
\hline \multirow{2}{*}{$\begin{array}{l}\text { Animal } \\
\text { Groups }\end{array}$} & Licking time(s) & \multirow{2}{*}{$\begin{array}{c}\text { Inhibition } \\
(\%)\end{array}$} \\
\hline & Mean \pm SEM & \\
\hline Control (2 ml/kg) & $293.8 \pm 2.10$ & $\bar{\square}$ \\
\hline ARME (200 mg/kg) & $123.8 \pm 2.23^{\star * *}$ & 57.86 \\
\hline ARME (400 mg/kg) & $98.2 \pm 2.65^{* * *}$ & 66.57 \\
\hline ARME (800 mg/kg) & $74.2 \pm 1.47^{* * *}$ & 74.74 \\
\hline Ibuprofen (40 mg/kg) & $104.5 \pm 2.74^{\star \star *}$ & 64.43 \\
\hline
\end{tabular}

Values are stated as mean \pm SEM $(n=5) .{ }^{* * *}=p<0.001$, compared to control. Aitchisonia rosea methanol extract

Effect of ARME on Acetic Acid Prompted Writhing

Treatment with ARME at $200,400,800 \mathrm{mg} / \mathrm{kg}$ doses significantly $(p<0.001)$ and dose dependently subdued abdominal constrictions as $47.73 \%, 58.43 \%$ and $68.31 \%$, respectively analogous to ibuprofen (62.55\%) as demonstrated in Table 3.

\section{Effect of ARME on Formalin Induced Paw Licking}

The mice administered ARME unveiled a remarkably $(p<0.001)$ shorter mean licking time for instance,
$57.86 \%, 66.57 \%$ and $74.74 \%$ at 200,400 and 800 $\mathrm{mg} / \mathrm{kg}$ doses, in that order in contrast to control group mice. Besides, the mice treated with reference drug ibuprofen also exhibited a notable reduction (64.43\%) in mean itching period (Table 4).

\section{DISCUSSION}

The existing study was intended to appraise antiinflammatory and analgesic potential of methanolic 
extract of Aitchisonia rosea in mice models of inflammation and pain.

Carrageenan and egg albumin induced mice paw edema are biphasic models of inflammation. Serotonin and histamine stimulates paw edema in $1^{\text {st }}$ phase while, prostaglandins, leukotriene and bradykinin maintains inflammation in $2^{\text {nd }}$ phase [1]. Besides, these inflammatory intermediaries prompt the efflux of edematous fluid, plasma proteins and neutrophils owing to increased vascular permeability and blood flow [11]. In the current study, paw edema was significantly reduced after ARME treatment. The study also established that ARME treatment is capable of reducing inflammatory reaction in either phase, which propose that ARME might impede the assembly of aforementioned inflammatory intermediaries similar to that produced by NSAIDs.

Acetic acid induced algesia in mice is a pertinent model to appraise analgesic ability of test substances. The discharge of inflammatory intermediaries (arachidonic acid, cyclooxygenase, prostaglandins, histamine, bradykinin and serotonin) upon injecting acetic acid produces algesia and abdominal writhing via peripheral nociceptive sensitization [1]. Results of the present study asserted that ARME dose dependently produced significant analgesic effect by reducing number of writhings and this response might be because of inhibition of arachidonic acid metabolite synthesis.

Furthermore, formalin persuaded hind paw licking test was also employed to evaluate analgesic effect in this study. A biphasic pain response is produced, in which $1^{\text {st }}$ phase is ascribed to bradykinin and tachykinins, however, $2^{\text {nd }}$ phase is owing to an inflammatory reaction instigated by tissue injury that prompts the discharge of serotonin, histamine, excitatory amino acids and prostaglandin. The first phase is normally inhibited by opioids and late phase is inhibited by NSAIDs and opioid both [12]. ARME significantly and dose dependently decreased the paw licking time in second phase that might be owing to the inhibition of inflammatory mediators, so it acts more like NSAIDs in reducing pain.

Accordingly, current findings have avowed that crude extract of Aitchisonia rosea possess preeminent potential to alleviate inflammation accompanied by algesia and may be allied to the presence of various phytoconstituents, as have been earlier reported in Aitchisonia rosea i.e., alkaloids, terpenoids, flavonoids, tannins and phenolics (quercetin, caffeic acid, chlorogenic acid and syringic acid) [4]. In addition, free radical scavenging and reducing potential of Aitchisonia rosea has previously been measured by using DPPH and reducing power assay [5]. Phytochemicals like flavonoids and saponins are well known for reducing pain sensitivity owing to their free radical scavenging properties [13], together with exert anti-inflammatory properties via inhibition of enzymes involved in production of inflammatory mediators and arachidonic acid metabolism [14]. Flavonoids also suppress prostaglandin synthesis that lead to several immune reactions [15]. Likewise, phenols, tannins and alkaloids have also been explored to be bestowed with anti-inflammatory potential [16].

\section{CONCLUSION}

In a nutshell, anti-inflammatory and analgesic potential of Aitchisonia rosea could plausibly be owing to alkaloids, flavonoids, phenols, tannins along with anti-oxidant effect of flavonoids. Nevertheless, activity directed fractionation of ARME to separate active constituents from plant and further studies to explicate probable mode of action are mandatory to rationalize its use.

\section{REFERENCES}

1. Gou KJ, Zeng R, Dong $Y$, Hu QQ, Hu HW, Maffucci KG, et al. Anti-inflammatory and analgesic effects of Polygonum orientale L. extracts. Front Pharmacol. 2017; 8:562. doi:10.3389/fphar.2017.00562

2. Amri O, Zekhnini A, Bouhaimi A, Tahrouch $S$, Hatimi A. Anti-inflammatory activity of methanolic extract from Pistacia atlantica Desf. leaves. Pharmacog J. 2018; 10(1):7176. doi:10.5530/pj.2018.1.14

3. Tamrat $\mathrm{Y}$, Nedi T, Assefa S, Teklehaymanot $\mathrm{T}$, Shibeshi W. Anti-inflammatory and analgesic activities of solvent fractions of the leaves of Moringa stenopetala Bak. (Moringaceae) in mice models. BMC Complement Altern Med. 2017; 17(1):473. doi: 10.1186/s12906-017-1982-y.

4. Rasool S, Khan FZ, Ahmad M. Evaluation of anticonvulsant, antimicrobial and hemolytic activity of Aitchisonia rosea. Bangladesh $\mathrm{J}$ 
Pharmacol. 2015; 10(4):980-7. doi:10.3329/BJP.V1014.24153

5. Rasool S. Pharmacognostic, phytochemical and pharmacological investigation of Aitchisonia rosea and Berberis calliobotrys. Ph.D. Thesis, University of the Punjab, Lahore, Pakistan. 2016.

6. Tungmunnithum D, Thongboonyou A, Pholboon A, Yangsabai A. Flavonoids and Other Phenolic Compounds from Medicinal Plants for Pharmaceutical and Medical Aspects: An Overview. Medicines. 2018; 5:93. doi: 10.3390/medicines5030093

7. Ambriz-Pérez DL, Leyva-López N, GutierrezGrijalva EP, Heredia JB. Phenolic compounds: Natural alternative in inflammation treatment. A Review. Cogent Food Agric. 2016; 2: 1131412. doi: 10.1080/23311932.2015.1131412.

8. NRC. Guide for the care and use of laboratory animals. Washington DC, National Academy Press. 1996.

9. Alamgeer, $\mathrm{NH}$, Rasool S, Raza SA, Ahmad T, Ahsan $\mathrm{H}$, Mushtaq $\mathrm{MN}$, et al. Antiinflammatory, analgesic and antipyretic activities of the aqueous methanolic extract of Berberis calliobotrys in albino mice. Acta Pol Pharm. 2016; 73(3):717-723. PMID: 27505907

10. Alamgeer,MU, Mushtaq MN, Khan HU, Maheen S, Malik MN, Ahmad T, et al. Evaluation of anti-inflammatory, analgesic and antipyretic activities of Thymus serphyllum Linn. in mice. Acta Pol Pharm. 2015; 72(1):113-8. PMID: 25850206

11. Yankanchi SR, Koli SA. Anti-inflammatory and analgesic activity of mature leaves of methanol extract of Clerodendrum inerme L. (Gaertn). J Pharm Sci Res. 2010; 11:782-5.

12. Bhutia YD, Vijayaraghavan R, Pathak U. Analgesic and anti-inflammatory activity of amifostine, DRDE-07, and their analogs, in mice. Indian J Pharmacol. 2010; 42(1):1720. doi: $10.4103 / 0253-7613.62401$.

13. Kaushik D, Kumar A, Kaushik P, Rana AC. Analgesic and Anti-Inflammatory Activity of Pinus roxburghii Sarg. Adv in Pharmacol Sci. 2012; 2012:245431. doi: $10.1155 / 2012 / 245431$

14. Sawadogo WR, Boly R, Lompo M, Some N. Anti-inflammatory, analgesic and antipyretic activities of Dicliptera verticillata. Int $\mathrm{J}$ Pharmacol. 2006; 2:435-438. doi:10.3923/ijp.2006.435.438

15. Jothimanivannan C, Kumar RS, Subramanian N. Anti-inflammatory and analgesic activities of ethanol extract of aerial parts of Justicia gendarussa Burm. Int J Pharmacol. 2010; 6:278-83. doi: 10.3923/ijp.2010.278.283

16. Khan FA, Zahoor M, Khan E. Chemical and biological evaluation of Ranunculus muricatus. Pak J Pharm Sci. 2016; 29:50310. PMID: 27087095 